Andrew Young School of Policy Studies Research Paper Series

Working Paper 06-04

February 2006

Department of Economics

\title{
The Impossibility of a Perfectly Competitive Labor Market
}

Bruce E. Kaufman Georgia State University

This paper can be downloaded at:

http://aysps.gsu.edu/publications/2006/index.htm

The Social Science Research Network Electronic Paper Collection: http://ssrn.com/890320 
The Impossibility of a Perfectly Competitive Labor Market

$$
\text { by }
$$

\author{
Bruce E. Kaufman \\ Department of Economics \\ Georgia State University \\ Atlanta, GA 30303
}

February 24, 2006

Bkaufman@gsu.edu

JEL D41, J4, B52. 
The Impossibility of a Perfectly Competitive Labor Market

\begin{abstract}
Using the institutional theory of transaction cost, I demonstrate that the assumptions of the competitive labor market model are internally contradictory and lead to the conclusion that on purely theoretical grounds a perfectly competitive labor market is a logical impossibility. By extension, the familiar diagram of wage determination by supply and demand is also a logical impossibility and the neoclassical labor demand curve is not a well-defined construct. The reason is that the perfectly competitive market model presumes zero transaction cost and with zero transaction cost all labor is hired as independent contractors, implying multi-person firms, the employment relationship, and labor market disappear. With positive transaction cost, on the other hand, employment contracts are incomplete and the labor supply curve to the firm is upward sloping, again causing the labor demand curve to be ill-defined. As a result, theory suggests that wage rates are always and everywhere an amalgam of an administered and bargained price.
\end{abstract}

The heart of neoclassical economics is the model of competitive markets. Kniesner and Goldsmith (1987:1241) comment, for example, “The auction-market analysis of prices and quantities is the core of neoclassical economics.” What is true in neoclassical economics writ large is also true in applied subfields, such as labor economics. Thus, Manning (2003: 11) observes, “Currently, labor economics consists of the competitive model with bits bolted onto it when necessary to explain away anomalies.” The competitive model gives rise, in turn, to what is arguably the most important diagram in modern labor economics - the diagram of wage determination by demand and supply.

Institutional, post-Keynesian, and other heterodox economists have for many years expressed skepticism about the theoretical and empirical validity of the competitive model of labor markets (e.g., Hodgson, 1988; Vickers, 1996; Streeck, 2005). This paper adds another dimension to this commentary using a theoretical line of reasoning that is simple, logically compelling, but not previously developed. 
In particular, I argue that on closer inspection the assumptions of the competitive labor market model are internally contradictory and lead to the conclusion that on purely theoretical grounds a perfectly competitive labor market is a logical impossibility. By extension, the familiar diagram of wage determination by supply and demand is also a logical impossibility and the neoclassical labor demand curve is not a well-defined construct. The reason is that the perfectly competitive market model presumes zero transaction cost and with zero transaction cost all labor is hired as independent contractors, implying labor services come from product markets and multi-person firms, the employment relationship, and labor markets all disappear. With positive transaction cost, on the other hand, labor markets exist but employment contracts are incomplete and the labor supply curve to firms is upward sloping. In this situation (e.g., monopsony) the labor demand curve is no longer a well-ordered, continuous and monotonic relationship between price and quantity. As a result, supply and demand cannot determine a unique market wage, leaving firms to set the wage as some form of administered or bargained price. Not only does this conclusion undercut one of the core theoretical constructs of the neoclassical paradigm, it does so using a theoretical concept - the transaction and transaction cost - that lies at the heart of institutional economics.

\section{Overview of the Argument}

The essential premise of institutional economics is that "institutions matter" in explaining and understanding economic outcomes and the theory and tools of neoclassical economics are in fundamental respects inadequate for fully illuminating this fact 
(Hodgson, 1988; Furubotn and Richter, 1997). The institution considered in this paper is the labor market and the employment relationship.

Generically considered, “labor” is a factor input involving the application of human effort to the production of goods and services. When, however, economists speak of a labor market and its various constituent components and outcomes, such as labor demand and supply curves and wage rates and employment levels, they transition from generic labor to a particular institutionalized form of labor. Human work effort, for example, can be provided by slaves, serfs, independent contractors, and unpaid family members. None of these forms of labor, however, are traded in what economists consider a labor (factor) market nor are they paid a "wage.” Further, while the buyer’s demand for the labor of a slave or an independent contractor must in some broad way vary inversely with the cost (Becker, 1962), this relationship is also not what economists ordinarily have in mind when they speak of a labor demand curve. Rather, a labor market presumes the existence of an employment relationship; that is, firms are the "employer" who go to the labor market and hire people as "employees" to provide a certain amount of labor services and follow the directions of the employer in return for a certain amount of remuneration per time period. Illustratively, Hamermesh states in his authoritative book Labor Demand (1993, p. 3, emphasis in original) that "the demand for labor is any decision made by an employer regarding the company's workers - their employment, their compensation, and their training.” In a similar vein, Milgrom and Roberts (1992, p. 327, emphasis added) state, "The study of labor markets, employment, and wages is a major element of standard neoclassical economics.” The neoclassical labor demand curve 
is thus a specialized institutional construct in that it presumes the existence of multiperson firms with jobs to fill who hire workers as employees to perform them.

In neoclassical theory the labor market and employment relationship are simply taken as "givens" and the analysis proceeds. In institutional economics, however, the labor market and employment relationship are endogenous variables, as suggested by the distinction often made between "make versus buy” (Williamson, 1985; Furubotn and Richter, 1997; Kaufman, 2004a). The task of institutional theory, therefore, is to determine when and under what conditions labor for production is obtained from a labor market versus some other form of institution (slavery, independent contractor, etc.). This perspective immediately opens-up the theoretical possibility that in some situations production will proceed without the existence of a labor market (e.g., an economy composed solely of $\mathrm{N}$ family farms). The insight of this paper is that such a situation occurs when an economy is characterized by a condition of zero transaction cost $-\mathrm{a}$ condition that is in turn fulfilled when the assumptions of the neoclassical perfectly competitive labor market model are met. Thus, the conclusion is that the model of a perfectly competitive labor market model is a logical impossibility because the nature of its assumptions precludes the existence of the very object it seeks to theorize.

To demonstrate this point, I sequentially consider two cases. The first is an economy with zero transaction cost, the second is an economy with positive transaction cost. The zero transaction cost case exposes the crucial contradiction in the neoclassical theory and is thus the core part of the argument; consideration of the positive transaction cost case is necessary, however, to ensure that there is no theoretical escape. For both cases, I argue, logic suggests a well-defined (continuous, monotonic) labor demand curve 
cannot exist. Without such a labor demand curve, in turn, there can be neither a perfectly competitive labor market nor the most important outcome of such a market -- a unique, market-determined wage rate parametric to the individual firm.

\section{Zero Transaction Cost}

The concept of a "transaction” was coined by Commons (1934) in Institutional

Economics. He defines it (p. 55) as the "legal transfer of ownership.” Although Commons did not proceed to define transaction cost, the logical inference is that it represents the real resource cost of transferring ownership (property rights) through the contracting process - specifically the negotiation, execution and administration of formal and informal contracts (Kaufman, 2003). This conceptualization broadly matches that of other people, such as Reder (1999: 223) who defines transaction cost as the "value of resources used to obtain and enforce agreement on contract terms between two (or more) legally distinct entities.” Commons proceeds to posit two basic mechanisms by which the transfer of ownership rights can be coordinated in an economy: voluntary exchange in markets (“bargaining transactions”) and unilateral command in organizations issued by a superior to a subordinate ("rationing transactions,” as directed by a president, CEO, or household head in a government, firm, or family; and "managerial transactions" where a boss commands workers to expend labor power and thus transfer work effort from the seller to the buyer). This distinction is now popularly known in the literature of institutional economics as “make versus buy” (Furubotn and Richter, 1997). The basic idea is that a good or service can either be made in-house or purchased through a market, 
with the choice of institutions determined by the goal of minimizing the sum of transaction and production cost.

Coase (1937) and Williamson $(1975,1985)$ separately developed the transaction cost idea and applied it in a more transparent and focused way to the issue of economic organization. The link to Commons is, however, acknowledged by Williamson. They note that the neoclassical perfectly competitive model rests on an assumption of zero TC (also see Reder, 1999; Jacobsen and Skillman, 2004). The reason is that this model implicitly assumes the contracting process and exchange of ownership rights is frictionless; i.e., takes place at zero cost. Zero TC arises, in turn, from the interactive effect of several of the perfectly competitive model's key assumptions: perfect human rationality, perfect information, and perfect legal enforcement of contracts. With these assumptions in place, economic agents are able to exchange and protect property rights at no cost, leading via the fundamental welfare theorem of neoclassical economics and the Coase theorem of TC economics to the conclusion that voluntary exchange will realize all feasible gains from trade (i.e., will lead to efficient, Pareto optimal outcomes).

Institutional economists have questioned both the theoretical validity and empirical relevance of these conclusions. In effect, they are arguing that the thoroughgoing consideration of "frictions" substantially alters or invalidates the predictions of the core version of neoclassical theory. In this regard, they are happy to find support from Stigler's (1972: 12) observation that "The world of zero transaction cost turns out to be as strange as the physical world would be without friction.”

One such friction and source of transaction cost is Simon's (1982) concept of “bounded rationality” - the idea earlier advanced by Commons (1934:p. 874; Kaufman, 
1999) that while human behavior is in large degree purposive and self-interested it is nonetheless systematically influenced by “stupidity, ignorance and passion.” Another important friction is imperfect information and fundamental uncertainty. Influenced by the work of Frank Knight (1921), for example, Commons asserts that institutional economics (p. 107) "investigates how our own minds and the world around us actually behave in a society of human beings whose future is frankly recognized as unpredictable.” And, finally, a third friction is government's imperfect ability to protect property rights and enforce contracts due to restricted information and limited sanctions (Commons, 1934: 692-97). The result of these fundamental imperfections is that the contracting process is necessarily less than perfect (frictionless) and economic agents must therefore spend real resources to negotiate, execute and enforce the transfer and ownership of property rights.

In his seminal article "The Nature of the Firm," Coase (1937) also notes with Commons that economic activity can be coordinated by the twin mechanisms of markets and prices or organizations and command. The question he posed was what determines the boundary line between the two, and the answer he gives is that "a firm will tend to expand until the costs of organizing an extra transaction within the firm become equal to the costs of carrying out the same transaction by means of an exchange on the open market..." An obvious implication of this decision rule is that if transaction cost is zero then markets are always and everywhere favored over (multi-person) firms, for using the former is frictionless and thus impossible to improve upon. This insight led Coase (1988: 14) to later observe "in the absence of transaction costs, there is no economic basis for the existence of the firm." [Coase is speaking of multi-person firms with an employment 
relationship, not a single person firm such as a sole proprietorship.] Demsetz (1991) notes that this conclusion leads to a neoclassical general equilibrium economy of perfect competition (or what he prefers to label "perfect decentralization") in which all exchange between people takes place through markets coordinated by price and firms dissolve into their lowest possible level of organization -- a myriad of one person production units. Commons (p. 108) called this an economy of “extreme individualism” (Kaufman, 2003).

The logical contradiction in the model of a perfectly competitive labor market now comes into view. If multi-person firms disappear in a world of zero transaction cost, so too must the employment relationship. Coase's article hints at this conclusion but does not directly state it. A more explicit articulation of this point is made by (among others) Herbert Simon (1951), Steven Cheung (1983), and Gregory Dow (1997).

Simon notes that a firm can obtain labor in two different ways: through an employment contract and a "sales contract." An employment contract gives the employer the legal authority to direct and control the labor services of the employee (within limits), in return for paying the employee a sum of money. A firm can also obtain labor services by hiring an independent contractor for an agreed-upon sum of money, typically consummated through a sales contract. The sales contract specifies the tasks to be completed and performance standards but gives the contractor the authority to control the production process. The employment contract, according to Simon, is attractive because in a world of bounded rationality and imperfect foresight the entrepreneur cannot anticipate ex ante to the start of production all the tasks and contingencies the worker must perform, thus giving the entrepreneur the flexibility to continually readjust and redeploy labor as production proceeds. The downside of the employment contract, 
however, is that its large extent of contractual openness exposes the worker to a greater degree of uncertainty and risk regarding work load and work conditions, leading workers to demand a higher rate of pay as a compensating differential.

Although Simon did not introduce the concept of transaction cost into his analysis, clearly it plays a strategic role in determining whether the firm opts for a sales or employment contract. In a world of substantial bounded rationality and imperfect information, transaction cost is high and the employment contract is favored; in a world of zero transaction cost the legal right of control over the worker's time has no economic value (since all terms, conditions, and performance expectations can be costlessly written into a complete contract) and firms would always opt to use a sales contract.

Cheung builds on Coase and Simon and draws out an additional key insight. He observes that switching from one mode of contracting for labor to the other involves a switch from using the product market to obtain labor services (independent contractors) to using the labor market (employees). Thus, he notes (p. 3), "The growth of a firm may then be viewed as the replacement of a product market by a factor market, resulting in a saving of transaction cost." An obvious implication is that in a world of zero transaction cost factor markets completely disappear, replaced by buying and selling through product markets. He states in this regard (p. 4), "If all costs of transactions were zero, a customer buying a pin would make a separate payment to each of the many contributing to its production.... In such a case, a large number of product prices would direct the production of the single pin. In such a world it would be redundant to speak of a product market and a factor market. The two would be inseparable." 
Building on these insights, Dow articulates the central point that makes the model of a perfectly competitive labor market internally contradictory. He notes, firstly, that a condition of zero transaction cost allows the owner of the firm to write a complete and costless contract for labor services. Given this, Dow states (pp. 58-9): "If labor were bought and sold using complete contracts, labor services would become just another commodity, no different from apples or toothpaste. Firms would buy whatever services were required at the moment and pay the going market price for these services. In such a world, employees would be indistinguishable from contractors: everyone would in effect be self-employed." This result holds true, it may be noted, even if firms are large-scale, capital intensive enterprises. In this case, with zero transaction cost it is feasible for the owner of the enterprise to write a complete contract that rents a discrete portion of the capital stock to individual independent contractors, such as a restaurant owner who rents tables to individual contractors selling "waiter services."

The central point may thus be simply stated. The model of a perfectly competitive labor market is a logical impossibility because it presumes zero transaction cost but the very condition of zero transaction cost causes the labor (employee) market to disappear. The implication with regard to the standard diagram of wage determination in a competitive labor market is equally significant. This diagram also presumes zero transaction cost, but if labor markets and the employment relationship disappear then so does the market demand curve for labor. The concept of a "wage rate," as a distinct price for the factor labor, also loses meaning. There remains, however, demand and supply curves for "generic labor" and, as Becker (1962) demonstrates, the demand function must, in a world of finite budget constraints, have a negative slope. However, these types 
of labor demand and supply curves are coordinated, not by wage rates in traditional labor markets, but by price adjustments in competitive product markets as hundreds of thousands of self-employed independent contractors buy and sell labor services in the form of intermediate goods and services. What holds true for the two dimensional (price/quantity) labor market also applies to the three (or N) dimensional case. That is, if transaction cost is zero then prices in the product market can still adjust to account for all variations in not only quantity but also quality of jobs and labor conditions, thus allowing economic agents to execute costless complete contracts that make superfluous an employment relationship.

Importantly, while the labor market disappears in either the two or $\mathrm{N}$ dimensional case, the efficiency properties of the competitive economy (summarized in the fundamental welfare theorems) continue to hold. What has changed is the institutional architecture through which the economy generates the Pareto optimal level of output. That is, market forces and the invisible hand still lead to the efficient level of output, but the production of this output is done not with employees obtained from the labor market but with independent contractors from the product market.

One possible reaction to the argument developed here is that it changes nothing of substance for the core of economic theory or, alternatively, that it is largely an exercise in semantics. At a very high level of abstraction (e.g., general equilibrium theory), these perspectives have some merit. At a lower level of abstraction, however, there seem to be genuine implications of significance. For example, although "realism of assumptions” trades at a significant intellectual discount in economics, surely one may question the predictive accuracy of a competitive model when it precludes the existence of as 
fundamental and ubiquitous a phenomenon as a labor market. This analysis also suggests that labor markets are inherently imperfect (in the economist's sense) since the mere existence of multi-person firms implies positive transaction cost and, thus, imperfect information and other associated sources of friction. Many interesting issues in modern labor economics, such as efficiency wages and internal labor markets, also arise (in part) from positive transaction cost. I also note that only if labor markets and an employment relationship exist is there an intellectual raison d'etre for a separate field of study called industrial (employment) relations (Budd, 2004; Kaufman, 2004b). And, finally, the existence of an employment relationship also implies the existence of a hierarchial authority relation in firms and an asymmetry in power between employers and employees, mandated in the law by the legal obligation of employees to do the bidding of the employer (within limits) and made possible in practice by the less than perfect nature of labor markets. This conclusion is in marked contrast to the position of many neoclassical economists who deny that employers have a power advantage over employees in internal firm governance (e.g., Alchian and Demsetz, 1972).

\section{Positive Transaction Cost}

The only way in theory for a labor market to exist is to assume positive transaction cost. Then some entrepreneurs find it more cost effective to obtain labor through employment contracts than sales contracts with independent contractors. The question might then be posed: is it possible to have positive transaction cost and still generate the important properties and predictions of the perfectly competitive labor market model? This case must also be considered, therefore, in order to close the argument. 
Positive transaction cost arises from imperfect human rationality, imperfect information, and imperfect delineation and enforcement of property rights. I suggest two reasons why the presence of one or a combination of these three frictions will invalidate the model. Others may also exist. The first is because these frictions lead to incomplete labor contracts, the second is because they give rise to job search and an upward sloping labor supply curve to the firm. The effect of both is to make it impossible to derive a well-defined, continuous and monotonic neoclassical labor demand curve.

A labor contract is complete "when it is possible, at the moment of signing, to foresee all the circumstances that could arise while it is in effect, and to set out verifiable clauses for each of them” (Cahuc and Zylberberg, 2004: 308, emphasis in original). A principal cause of contract incompleteness is imperfect and asymmetric information conditions that lead to a host of contracting problems now popular in the modern research literature, such as principle-agent problems and moral hazard (Miller, 1991; Gibbons, 1997). But these problems were well-recognized by earlier generations of institutional economists, even if they did not (or could not) formalize them. Commons (1919: 22-3) states, for example, "the labor contract is not automatic and is not enforceable according to specifications. It is a new contract every day and every hour.... The laborer is bargaining while he is working."

The process of wage determination in a competitive labor market requires a welldefined and stable downward sloping demand curve. Neoinstitutional labor economists, such as Richard Lester (1964), long ago expressed severe doubts about this property of neoclassical theory, in part because standard theory treats labor as if it is an inert commodity that delivers a certain predetermined amount of labor services to the 
production function, like BTUs from coal or tensile strength from steel. But, in reality, labor is embodied in human beings and a large gap may exist between the labor time the employer buys in the employment contract and the actual amount of labor services (effort or “labor power”) provided by the workers. Even George Stigler (1952: 200), Lester’s arch-nemesis, recognized this fact, stating, "the most casual observation indicates great variation among individuals in their pace and efficiency of work.”

The evident implication of variable work effort is that the neoclassical labor demand curve, defined as the relationship between the price of labor $(\mathrm{W})$ and the number of workers/hours (L) desired by the firm, is unstable and ill-defined since at any $\mathrm{W}$ the marginal product can take a large range of values depending on the effort employees exert. The amount of effort exerted, in turn, depends on a host of industrial relations factors long cited by institutional economists, such as fairness and management style.

Of course, one legitimate retort of neoclassical economists is that this damage is done to the theory only by violating one of its assumptions - that labor is of homogenous quantity/quality. While work effort is subject to considerable variation, if the dependent variable $\mathrm{L}$ in the labor demand function is redefined by indexing workers/hours by level of effort level - similar to the notion of an "Arrow-Debreu commodity” in general equilibrium theory - the conventional theory may be rescued, although at some cost to realism and predictive ability (Hamermesh, 1993: 55). Alternatively, another option is to endogenize work effort and solve for the equilibrium value of the wage/effort bargain, such as in efficiency wage models (e.g., Akerlof and Yellen, 1990; Solow, 1990). The solution value of work effort could, in turn, be treated as the labor input in the production function. Although this area of labor demand theory is largely uncharted territory, one 
can imagine that this procedure could potentially generate a well-defined marginal product schedule and labor demand curve -- albeit possibly one that is now upwardsloping if work effort is highly elastic with respect to the wage (Perlman, 1969: 50-56).

As long as employment contracts are incomplete, however, these stratagems either fail or turn the theory into an ex post rationalization of observed W/L combinations. The reason is that to form a labor demand curve the employer must estimate the marginal product schedule prior to the commencement of the production process and, hence, prior to knowing the outcome of the wage/effort bargain. With a complete contract, the employer and worker would agree to a particular level of effort (either the indexed level or the solution outcome of the wage/effort bargain model) and this effort level, being locked-in, would be delivered in the future. But, the large literature on moral hazard and the principal-agent problem show that with hidden/asymmetric information and incomplete contracts the actual level of work effort delivered by the worker (and demanded by the employer) will systematically diverge from the amount promised at the signing of the contract. As a result, Malcomson (1999: 2364) concludes from a survey of this literature: "the equilibrium wage-employment combination in the models reviewed here do not typically correspond to intersections of demand and supply curves. Indeed, they may not correspond to points on either of those curves.” Even in the atypical case that such a model yields a point on the labor demand curve, the ability of an employer in a world of imperfect information and bounded rationality to calculate it in a determinative manner is highly unlikely. With an incomplete contract, therefore, the marginal product schedule and labor demand curve must necessarily appear to the employer as band of possible values rather than a well-defined line. Thus, instead of a 
unique equilibrium wage/employment (or wage/effort/employment) level as envisioned in competitive theory, a range of equilibrium wage rates and employment levels is possible. Accordingly, in the words of Kerr (1950: 282): "The operation of the job market does not determine wages but, rather, sets the limits within which they are fixed.” Similarly, this conclusion helps explain not only wage rigidity (Bewley, 1999; Fehr and Falk, 1999) but also Lester’s (1952) non-competitive “range theory” of wage determination and his long-standing contention that employment may not fall with a moderate hike in the minimum wage (Lester, 1964; also see Card and Krueger, 1995).

Positive transaction cost precludes competitive labor market outcomes and a competitive labor demand/supply diagram on a second count. Joan Robinson developed the model of monopsony and in doing so she noted (1969: 216) that "perfect competition among buyers [firms] requires that ... sellers [workers] are indifferent as to whom they provide with their wares [labor].” But with imperfect information (an element of positive transaction cost) workers are not indifferent between their current employer and other potential employers in the labor market. As Stigler (1962) first formally demonstrated, with imperfect information in labor markets workers must engage in a process of job search to discover terms and conditions of employment at other firms. With job search, under general and reasonable assumptions (i.e., that the employee separation rate is decreasing in the wage and the flow of recruits is increasing in the wage) the labor supply curve to the firm is no longer horizontal but upward sloped (Card and Krueger, 1995; Manning, 2003; Mitchell and Erickson, 2005). As long as search costs are positive, an employed worker will (ceteris paribus) only leave one job for another if the new job pays 
a higher wage. Likewise, a firm can cut pay and not all workers will immediately quit, as presumed in the competitive model (Slichter, 1931; Reynolds, 1946).

As long as the labor supply curve to the firm has any positive slope, the firm gains a degree of market power and can administratively set the wage. The importance of this fact for the present discussion is not that it allows possible exploitation of workers but that it means the market labor demand curve is no longer a well-defined downward sloping relationship. As is well known, an imperfectly competitive firm in the product market (e.g., a monopolist) has a well-defined marginal cost curve but not a well-defined supply curve, arising from the fact that the relationship between price and quantity supplied is in this case determined by both the marginal revenue and marginal cost curves. By parallel reasoning, an imperfectly competitive firm in the labor market (any firm with an upward sloping labor supply curve, such as a monopsonist) has a welldefined marginal revenue product schedule but not a well-defined neoclassical labor demand curve (Robinson, 1969; Fleisher and Kniesner, 1980: 198).

This conclusion does not deny the general proposition that there is at some broad level a negative relationship between the wage and quantity demanded of labor. Rather, it has three other important implications. The first is that the relation between the wage (W) and labor demand (L) is not monotonic since, as Manning $(2003,269)$ shows, this relationship is contingent on the value of the elasticity of the labor supply curve - a value that may well change at different levels of $\mathrm{W}$. The labor demand curve, to the degree it exists, thus may have gaps, an upward sloping section, or take the form of a band, all of which destroys (or degrades) the well-behaved and deterministic behavioral predictions of the perfectly competitive model. The second important insight is that wage rates must 
to some degree be an administered (employer-set) price in order to close the indeterminacy of the market (Dunlop, 1984). And, finally, labor markets in this case generate inefficient outcomes.

\section{Conclusion}

Based on simple reasoning, I have argued in this paper that the existence of a neoclassical perfectly competitive labor market is a logical impossibility. The basis for this hypothesis is ideas developed earlier by Commons, Coase, Williamson, and Robinson. If accepted, this argument implies the standard labor demand/supply diagram also cannot exist as a well-defined construct, and that the "law of supply and demand" is at best a somewhat loose theoretical approximation. A correlative conclusion, equally noteworthy, is that a well-defined neoclassical labor demand curve is also non-existent in a world of zero transaction cost and highly unlikely to exist in a world of positive transaction cost.

This set of conclusions is not based on realism of assumptions or deviant observations but instead rests on an internal contradiction of the theory itself. The contradiction is two-sided. If the model's assumption of zero transaction cost is granted, firms hire all labor through the product market in the form of independent contractors and the labor market, employment relationship, and labor (employee) demand curve disappear. If labor markets are assumed to exist, then transaction cost is positive, employment contracts are incomplete, the labor supply curve to the firm slopes upward, and the labor demand curve again is ill-defined. Either way, based on the criterion of logical consistency neither the model of a perfectly competitive labor market, the familiar 
diagram of market wage determination by labor demand and supply curves, or the neoclassical labor demand curve are well-defined theoretical constructs.

Two corollary theoretical predictions may also be cited that distinguish the neoclassical and institutional perspectives on the perfectly competitive model. These predictions, of course, are to be evaluated as a statement of central tendency, not as a literal description of reality. First, the former portrays wage rates as completely market determined; the latter predicts wage rates are always and everywhere a form of administered or bargained price - often heavily shaped and constrained by market forces but in the end determined by conscious management decision. Second, the perfectly competitive model predicts wage rates are highly flexible and readily adjust to maintain labor markets at full employment; the institutional model predicts wage rates are subject to some degree of indeterminacy and rigidity and labor markets may be characterized by long stretches of disequilibrium and involuntary unemployment (Bewley, 1999; Mitchell and Erickson, 2005).

Although I assert that the perfectly competitive labor market model is intrinsically flawed as a theoretical construct, I do not wish to be overly nihilistic Undoubtedly the competitive model, labor demand/supply diagram, and labor demand curve retain significant value as expository devices for illustrating basic principles of market wage/employment determination. And, despite the theoretical lacunas identified in this paper, they may also retain considerable usefulness as tools for structuring and informing empirical work to the degree the predictions of competitive theory represent good first approximations to observed behavior. This matter is a subject of long-standing controversy and is not one this paper seeks to directly inform or evaluate. Indirectly, 
however, this paper does lead to the inference that because the theory of a perfectly competitive labor market is logically flawed the empirical predictions from this theory are also likely to be correspondingly off-target (for one piece of suggestive evidence, see Machin and Manning, 2004). Here are interesting empirical issues for further research.

With due recognition given to the positive contributions of neoclassical theory, it remains my belief that the theoretical problems described above seriously compromise the intellectual integrity of the core paradigm that now dominates research in modern labor economics. The implication, however, is not to abandon theorizing in labor economics but to devote further attention to models of imperfect competition and the interface between organizational and market forces in price/wage determination, as long advocated by institutional, post-Keynesian, and other economists (Dunlop, 1984; Arestis, 1996; Manning, 2003; Budd, 2004; Kaufman, 2004a). Most heartening, I believe, is that this paper demonstrates institutional economics does indeed have a theoretical core and contribution to make to economic science and labor research.

Some (perhaps many) economists will, nonetheless, view the results of this paper more as a curiosum that leaves unchallenged the main corpus of neoclassical economics. A popular view, after all, is that modern labor economics has long since moved beyond the simple competitive model (Boyer and Smith, 2001). If this view is accepted, however, it leads to further unsettling implications. For example, Lazear (2000) notes two other core assumptions of neoclassical economics are that markets lead to invisible hand outcomes and, correlatively, these outcomes are efficient. Without a competitive labor market in the background, the question of how maximizing/rational economic agents (the other theoretical pillar of the neoclassical paradigm) are able to generate these beneficent 
results would seem to lack an obvious answer. Second, labor economists commonly examine the labor market effects of unions and minimum wages using the competitive wage as the starting point. Doing so, however, effectively pre-judges the issue since if one starts with an efficient allocation of resources these institutions can only do harm. If a competitive wage does not exist, however, room is then opened up in both theory and reality for these institutions to do good as well as harm (Craypo, 1997; Kaufman, 2004c). This conclusion would open up the neoclassical paradigm, however, to a degree of indeterminacy, institutional intervention, and policy activism that has long been resisted.

\section{REFERENCES}

Akerlof, George, and Janet Yellen. 1990. “The Fair Wage-Effort Hypothesis and Unemployment,” Quarterly Journal of Economics, Vol. 105, No. 2, 255-84. Alchian, Armen, and Harold Demsetz. 1972. "Production, Information Costs, and Economic Organization,” American Economic Review, Vol. 72, No. 5, pp. 77795.

Allen, D. 1997. "Property Rights, Transaction Costs, and Coase: One More Time.” In S. Medema, ed., Coasean Economics: Law and Economics and the New Institutional Economics, pp. 105-18. Boston: Kluwer.

Arestis, Philip. 1996. “Post-Keynesian Economics: Towards Coherence,” Cambridge Journal of Economics, Vol. 20, pp. 111-35.

Becker, Gary. 1962.”Irrational Behavior and Economic Theory,” Journal of Political Economy, Vol. 70, No. 1, pp. 1-13. 
Bewley, Truman. 1999. Why Wages Don't Fall during a Recession. Cambridge: Harvard University Press.

Boyer, George, and Robert Smith. 2001. "The Neoclassical Tradition in Labor Economics,” Industrial and Labor Relations Review, Vol. 54 (January), pp. 199 $-223$.

Budd, John. 2004. Employment with a Human Face: Balancing Efficiency, Equity, and Voice. Ithaca: Cornell University Press.

Cahuc, Pierre and André Zylberberg. 2004. Labor Economics. Cambridge: MIT Press.

Card, David, and Alan Krueger. 1995. Myth and Measurement: The New Economics of the Minimum Wage. Princeton: Princeton University Press.

Cheung, Steven. 1983. "The Contractual Nature of the Firm," Journal of Law and Economics, Vol. 26 (April), pp. 1-21.

Coase, Ronald. 1937. “The Nature of the Firm,” Economica, Vol. 4 (November), pp. 386-405. . The Firm, the Market, and the Law. 1988. Chicago: University of Chicago Press.

Commons, John. 1919. Industrial Goodwill. New York: McGraw-Hill. . 1934. Institutional Economics: Its Place in Political Economy. New York: MacMillan.

Craypo, Charles. 1997. “Alternative Perspectives on the Purpose and Effects of Labor Standards Legislation.” In B. Kaufman, ed., Government Regulation of the Employment Relationship. Madison, WI: Industrial Relations Research Association, pp. 221-52. 
Demsetz, Harold. 1991. "The Theory of the Firm Revisited," in Oliver Williamson and Sidney Winter, eds., The Nature of the Firm: Origins, Evolution, and Development. Oxford: Oxford University Press, pp. 159-78.

Dow, Gregory. 1997. "The New Institutional Economics and Employment Regulation," in B. Kaufman, ed., Government Regulation of the Employment Relationship, Madison: Industrial Relations Research Association, pp. 57-90.

Dunlop, John. 1984. "Industrial Relations and Economics: The Common Frontier of Wage Determination.” In Industrial Relations Research Association, Proceedings of the Thirty-Seventh Annual Meeting, pp. 9-23. Madison: Industrial Relations Research Association.

Fehr, Ernst, and Armin. Falk. 1999. "Wage Rigidity in a Competitive Incomplete Contract Market,” Journal of Political Economy, Vol. 107 (Feb), pp. 1106 -34.

Fleisher, Belton, and Thomas Kniesner. 1980. Labor Economics: Theory, Evidence and Policy, $2^{\text {nd }}$ ed. Englewood-Cliffs: Prentice-Hall.

Furubotn, Erik, and Rudolph Richter. 1997. Institutions and Economic Theory: The Contributions of the New Institutional Economics. Ann Arbor: University of Michigan Press.

Gibbons, Robert. 1997. "Incentives and Careers in Organizations.” In D. Kreps and K. Wallis, eds., Advances in Economics and Econometrics: Theory and Applications, Vol. 2, pp. 1-37. New York: Cambridge University Press.

Hamermesh, Daniel. 1993. Labor Demand. Princeton: Princeton University Press. Hodgson, Geoffrey. 1988. Economics and Institutions: A Manifesto for a Modern Institutional Economics. Philadelphia: University of Pennsylvania Press. 
Jacobsen, Joyce, and Gilbert Skillman. 2004. Labor Markets and Employment Relationships: A Comprehensive Approach. Malden, MA: Blackwell.

Kaufman, Bruce. 1999. "Emotional Arousal as a Source of Bounded Rationality,” Journal of Economic Behavior and Organization, Vol. 38, No. 1, pp. 135-44. . 2003. "The Organization of Economic Activity: Insights from the Institutional Theory of John R. Commons,” Journal of Economic Behavior and Organization, Vol. 52, No. 1, pp. 71-96. . 2004a. "Employment Relations and the Employment Relations System: A Guide to Theorizing.” In B. Kaufman, ed., Theoretical Perspectives on Work and the Employment Relationship. Champaign, IL: Industrial Relations Research Association, pp. 41-75. . 2004b. The Global Evolution of Industrial Relations: Events, Ideas, and the IIRA. Geneva: International Labor Organization. . 2004c. "What Unions Do: Insights from Economic Theory,” Journal of Labor Research, Vol. 25, No. 3, pp. 351-82.

Kerr, Clark. 1950. "Labor Markets: Their Character and Consequences,” American Economic Review, Vol. 40 (May), pp. 278-91.

Kniesner, Thomas, and Arthur Goldsmith. "A Survey of Alternative Models of Aggregate U.S. Labor Market,” Journal of Economic Literature, September 1987, 25 (September), pp. 1241-80.

Knight, Frank. 1921. Risk, Uncertainty, and Profit. New York: Harper and Row. Lazear, Edward. 2000. “Economic Imperialism,” Quarterly Journal of Economics, Vol. 115 (February), 99-147. 
Lester, Richard. 1952. “A Range Theory of Wage Differentials,” Industrial and Labor Relations Review, Vol. 5 (July), pp. 483-500. . 1964. Economics of Labor, $2^{\text {nd }}$ ed. New York: MacMillan.

Machin, Stephen, and Alan Manning. 2004. “A Test of Competitive Labor Market Theory: The Wage Structure Among Care Assistants in the South of England.” Industrial and Labor Relations Review, Vol. 57 (April), pp. 371-85.

Malcomson, James. 1999. "Individual Employment Contracts.” In O. Ashenfelter and D. Card, eds., The Handbook of Labor Economics, Vol. 3B, pp. 2291-2372. New York: North-Holland.

Manning, Alan. Monopsony in Motion. Princeton: Princeton University Press, 2003.

Milgrom, Paul, and John Roberts. 1992. Economics, Organization \& Management. Englewood-Cliffs, NJ: Prentice-Hall.

Miller, Gary. 1991. Managerial Dilemmas. Cambridge: Cambridge University Press. Mitchell, Daniel J.B., and Christopher Erickson. 2005. “De-Unionization and Macro Performance: What Freeman and Medoff Didn’t Do,” Journal of Labor Research, forthcoming.

Perlman, Richard. 1969. Labor Theory. New York: Wiley.

Reder, Melvin. 1999. Economics: The Culture of a Controversial Science. Chicago: University of Chicago Press.

Reynolds, Lloyd. 1946. “The Supply of Labor to the Firm,” Quarterly Journal of Economics, Vol. 60 (May), pp. 390-411.

Robinson, Joan. 1969. The Economics of Imperfect Competition, $2^{\text {nd }}$ ed. New York: MacMillan. 
Rosen, Sherwin. 1974. “Hedonic Prices and Implicit Markets,” Journal of Political Economy, Vol. 82 (January/February), pp. 34-55.

Simon, Herbert. "A Formal Theory of the Employment Relationship," Econometrica, 1951, 19, pp. 293-303. . 1982. Models of Bounded Rationality, Vol. 2. Cambridge: MIT Press.

Slichter, Sumner. 1931. Modern Economic Society, $2^{\text {nd }}$ ed. New York: Henry Holt. Solow, Robert. 1990. The Labor Market as a Social Institution. New York: BasilBlackwell.

Stigler, George. 1952. The Theory of Price, rev. ed. New York: MacMillan. . 1962. "Information in the Labor Market," Journal of Political Economy, Vol. 70, No. 5, pp. 94-105. . 1972. "The Law and Economics of Public Policy: A Plea to Scholars,” Journal of Legal Studies, Vol. 1, No. 1, pp. 1-12.

Streeck, Wolfgang. 2005. “The Sociology of Labor Markets and Trade Unions.” In N. Smelser and R. Swedberg, eds., The Handbook of Economic Sociology, $2^{\text {nd }}$ ed., pp. 254-83. New York: Russell Sage.

Thurow, Lester. Dangerous Currents: The State of Economics. New York: Random House, 1983.

Vickers, Douglas. 1996. “The Market: The Tyranny of a Theoretical Construct.” In P. Arestis, ed., Employment, Economic Growth, and the Tyranny of the Market, pp. 1-18. Brookfield: Edward Elgar.

Williamson, Oliver. 1975. Market and Hierarchies, Analysis and Antitrust Implications. New York: The Free Press. . 1985. The Economic Institutions of Capitalism. New York: The Free Press. 